\title{
Liberty and liberties in Europe's federal republics
}

\author{
Thomas Maissen
}

Liberty was a core issue for the federal republics in early modern Europe. ${ }^{1}$ There were not many of them, and even fewer survived as political entities. ${ }^{2}$ The Confoederatio Bohemica was founded on 31 July 1619 to protect the estates of Bohemia against the Habsburg monarch who, however, managed to dissolve them within little more than a year in late $1620 .{ }^{3}$ To preserve their liberty, the Bohemians had elected the famous Winter King, Frederick $\mathrm{V}$, Elector Palatine. That the estates undertook to elect a new monarch helps us understand why federal republics and their liberties were particularly threatened. In times when endemic war Darwinistically selected those states that were to survive, a unified army and a military leader were indispensable. Beyond the meaning of personal freedom (sui iuris esse), 'Liberty' therefore could assume the rather negative implications of being alone and defenceless, exposed to the mercy of stronger powers. 'Liberties' meant something else: iura ac libertates were privileges which entitled their holders to rule themselves, although under the dominion of the overlord who granted the privileges. 4 Liberty was absolute and meant exposure to external threat; liberties were relative and meant protection within a hierarchical structure - protection given to inferiors and received from superiors. Liberties thus corresponded to the graduated structure of feudal societies, still very present in early modern Europe, while liberty stemmed from the classical, neo-Roman tradition that eventually became the core of the individualist theory of natural rights. 5 This chapter will discuss the co-existence of such different notions of freedom in

\footnotetext{
1. I thank Julia Bernheim (IAS Princeton) and Quentin Skinner for their great help in editing this paper in English.

2. Fröschl 1994. 3. Bahlcke 1997.

4. See also Lee, Chapter 14 in this book, for the German tradition of liberties as privileges.

5. Conze et al. 2004; Skinner 1998; Schreiner 1991.
} 
the two federal republics that lasted until the Napoleonic era: the United Provinces of the Netherlands and the Swiss Confederation. With a focus on religious freedom, the question will also be posed why a modern concept of liberty appeared first in the Netherlands and only much later in Switzerland.

To understand the meaning of 'vrijheid' and 'Freiheit' in the two federations, a preliminary look at their constitutions is necessary. They reveal considerable differences, but also major similarities, especially if the political structures are compared as ideal types to dynastic monarchies. ${ }^{6}$ In general, the contrasts can be summarised as follows. Government was institutionalised essentially on a provincial or local level; actually, the Dutch provinces and the Swiss cantons claimed sovereignty for themselves. The central government of the federation was weak and lacked administrative and military efficiency. There was no real court, and the Swiss Confederation, essentially a defensive league, did not even have a capital. Its Diet was held only a few times a year as a meeting of envoys in order to discuss common issues, but lacked directive powers: the sovereign cantons could decline whatever was decided at the Diet. In contrast, the States-General in The Hague already guaranteed some centralised unity, and so did the Grand Pensionary, the Council of State and above all the house of Orange that usually provided the stadtholder of Holland, Zealand and Utrecht, who was simultaneously captain-general of the confederate army in times of war and also claimed political leadership in times of peace. Still, the two republics could not dominate territories the way that dynastic (and absolutist) states could. Even with a dynastic element like the house of Orange, they were forced to find shared solutions for structural and political problems and thus compelled to collaborate within networks. Government both in the predominant cities and in the rural communities was polyarchic and co-opted new members of the ruling elite through election, not through hereditary succession. These elites were mostly urban and bourgeois, not aristocratic; the basis of their social and political power was economic enterprise, not warfare. This, however, occasioned internal strife insofar as the rural provinces as well as the rural cantons were economically less developed and quite dependent on warfare - in the Swiss case, mercenary services. Close to the urban areas, however, manufacturing and the puttingout system played a relatively large role in both republics, compared with the rather agricultural monarchies. So did trade, which was extremely international in the Dutch case and often crossed borders in Switzerland. Competitive exchange was the rule, not regulation and coercion in a mercantilist 
system; again, this applied more to the Dutch, as guilds played a major economic role in Switzerland. The army was a militia, strengthened in the Dutch case by mercenary troops (quite a few from Switzerland); it was not a standing professional army as established in the big monarchies in the second half of the seventeenth century. While the latter were imposing religious uniformity, the federal republics permitted different kinds of religious coexistence.

Several of these observations had already been made by early modern commentators. ${ }^{7}$ They also developed the opposition between repressive monarchies and republican liberty that has inspired modern discussions associated with authors such as Hans Baron, John Pocock or Quentin Skinner who have focused on Renaissance Italy and then on seventeenth-century England, but not on the continental federal republics. The latter, and especially the Dutch, have slowly made their way during recent decades into the discussions of republicanism. ${ }^{8}$ However, comparative studies are still rare, although a first essay, Jean François Le Petit's Nederlantsche Republycke... geconfereert ende vergeleken met die van de Swytersche cantoenen, appeared as early as 1615 . Le Petit pointed out that both countries became 'vrÿe Republÿcke' thanks to a similar fight for 'vryheydt' against Habsburg rule, as personified by the Austrian duke Leopold III and the Spanish king Philip II. ${ }^{9}$ Especially in the second half of the seventeenth century, both Dutch and Swiss authors displayed historical and political similarities. During the Dutch War that Louis XIV had precipitated in 1672 , an anonymous pamphlet was printed: L'affermissement des republiques de Hollande \& de Suisse (1675). It advocated an alliance between republics, and especially between the Dutch and the Swiss. A common past of defending themselves against the Habsburgs should unite them; the patrons of the alliance would be the Swiss Blessed Nicholas of Flüe, William of Orange, the first liberator of Holland ('le premier Liberateur de la Hollande'), and William Tell, who established the liberty of the Swiss ('le fondateur de la liberté des Suisses'). Liberté essentially means 'independence' in this context, but it is specifically the independence of a free state as opposed to the monarchical constitution which is not only repudiated in the case of Louis XIV, but also seen as a general threat: 'Toute sorte de Couronnes absoluës \& Ministres souverains doivent estre suspectes aux

7. Davids and Lucassen 1995 .

8. For a bibliographical essay see Kossmann 2000a: 19-23, who mentions among others Haitsma Mulier 1987; Mout 1988; Van Gelderen 1992; on 'Dutch republicanism' see particularly Kossmann 2000a: 169-93.

9. Le Petit 1615 , dedication and $387,422-3,446-8,465$; see also Van Schelven 1947: 753-4. For more recent comparative approaches see Holenstein 2008. 
Republicains' - all kinds of absolutist crowns and sovereign ministers must make republicans suspicious. ${ }^{10}$

Such language was not common at the time, especially not in the Swiss cantons that only rarely referred to themselves as 'republics' and still less as 'republicans'. They were still obsessed with religious strife and confessional loyalties. Indeed, besides the historical communities of the two countries, the anonymous author of the Affermissement also mentioned that even in religion they were similar, but then went on to maintain that religion no longer played a role in the building of alliances. It was a secular pact that the Affermissement proposed against the threat of royal absolutism. Thus Liberty became a secular mark of similarity between the two federal republics that until then had usually underlined their common Calvinist faith - at least those who were actually Calvinist. In the Netherlands, there was an important but politically marginalised Catholic minority, while in Switzerland there was even a majority of seven Catholic although mostly petty cantons. Five of them fought three minor civil wars against the big Protestant cantons of Zurich and Berne in 1531, 1656 and 1712; Basel and Schaffhausen, both Reformed, remained neutral in those conflicts. By exclusively insisting on 'liberty' as a common ground, the Affermissement tried to address both confessional groups in Switzerland as potential allies and providers of mercenaries who were then monopolised by the French.

This endeavour failed during the Dutch War, but emerged again when the War of the Grand Alliance (1688-97) broke out. At this time, the United Provinces sent an extraordinary envoy to Switzerland: Petrus Valkenier. In an earlier publication on the current troubles of Europe, Valkenier had already written that the two countries should unite in their defence of liberty, because their shared republican form of government was despised by all potentates everywhere. ${ }^{11}$ Blaming Louis XIV for dealing with sovereign republics as if they were his subjects, Valkenier deliberately used the language of modern constitutional law in addressing the Confederation as an absolute, independent, sovereign and equally neutral republic: 'A Assolute, Independente, Souveraine und zugleich auch Neutrale Republic.' ${ }^{12}$ These were exceptional words at least to Swiss ears unused to the language of constitutional and international law that stemmed from authors such as Jean Bodin and Hugo Grotius. What Valkenier sought to stress was that the Confederation, being both a sovereign and a neutral state, was not unilaterally bound by its earlier alliances to France, but could also hire out mercenaries to the 
United Provinces. Valkenier added several elements to the list of geographic and historical similarities between the two countries that predecessors like the Affermissement had established. It included the constitution, a defensive foreign policy without expansionism, and the desire for justice, profitable commerce and the development of factories. The harmony and sympathy that the two republics shared, according to Valkenier, should naturally lead to a security pact directed not only against France, but as a matter of principle against all monarchies, because monarchies resented republics in general and would overthrow them as soon as possible if the free states did not protect themselves through prudent treaties. ${ }^{13}$ In 1693 , Valkenier's arguments eventually won in the Protestant cantons: Zurich was the first to sign a treaty and send a battalion of mercenaries to the Dutch - thereby breaking the French monopoly on mercenaries.

Why was the political language of the Dutch unusual to Swiss ears, although it encompassed constitutional similarities that seem obvious to present-day readers? Only in these years did the fundamental difference between monarchies and republics become a real issue of Swiss statesmen and of political thought as far as there was any in the Confederation. To put it bluntly: it was mostly the Dutch, but e negativo also the French, who taught the Swiss 'republicanism' to be understood as a theoretical reflection both on sovereignty and on the problem of political freedom. That such a theoretical, legal approach to the issue emerged only late, in the seventeenth century, may sound surprising, because the Swiss Confederation was much older and had claimed freedom as its particular distinction for some time. Its origins dated back to the fourteenth century, and from the late fifteenth century on the tales of William Tell, his comrades and their oath of federation against tyranny had been part of national history and legitimation. In the most sophisticated of these narratives, the Chronicon Helveticum (1563), Aegidius Tschudi interpreted the revolt against the Habsburgs as regaining original liberty that the Swiss, or rather the Helvetians, had already possessed before the Roman conquest. ${ }^{14}$ This became one of the many humanist founding narratives that began with Leonardo Bruni's Etrurians and went on with Etienne Pasquier's Nos ancêtres les Gaulois or Grotius's presentation of the Batavians in his De antiquitate Reipublicae Batavicae (1610).

As for the United Provinces, they had started their revolt against the Spanish Habsburgs in the late 1560 , much later than the Swiss had started theirs against the Austrian branch of the dynasty. Their independence could 
be dated, at the earliest, to the Act of Abjuration (Plakkaat van Verlatinghe), signed by seventeen provinces in 1581 . The legitimacy of this act, deposing a king of divine right, was even more doubtful than in the Swiss case. That was one reason why the Dutch almost desperately tried to find a new king, a French or an English prince, or even a woman, Queen Elizabeth. Their rebellion was not a revolution against monarchy and monarchs in principle; it was directed against one very specific tyrant who had violated their good traditional rights and customs. The very first article in the Union of Utrecht in 1579, another founding document of the United Provinces, noted that the Dutch 'provinces will form an alliance, confederation, and union among themselves... in order to ... retain undiminished its special and particular privileges, franchises, exemptions'. ${ }^{15}$ Liberty hence meant independence, provincial autonomy and religious toleration as a collective right. ${ }^{16}$ It was only when the Dutch could not find a new king respectful of their privileges (the dominium politicum et regale) that they slowly realised that they had become what they had not intended to be: a republic. ${ }^{17}$ And it was only in the mid seventeenth century that a coherent theory of this republic was developed by authors such as the brothers De la Court and Spinoza. ${ }^{18}$

During the Eighty Years War, Dutch political thought was rather traditional and pragmatic, and focused less on philosophy than on history, as in Grotius's De antiquitate. Following the Aristotelian scheme, he and others defined the United Provinces as a mixed state, characterised by a monarchical element - the stadtholder - and the urban aristocracies. To justify their unusual constitution, the Dutch also looked to foreign parallels. The dialogue Emanuel-Erneste, probably written by Gerard Prouninck van Deventer in 1580 , rejected the Swiss model, because the effeminate Dutch lacked the 'ancient military discipline' of the Confederates and were addicted to the

15. Quoted in translation from Rowen 1972: 70. 16. Kossmann 1991: 286.

17. For the dominium politicum et regale see Koenigsberger 1986.

18. In this I follow Kossmann 2000a: 25-129, and Secretan 1990. Skinner 1978 and Van Gelderen 1992 offer a more modern reading of the founding texts of the Dutch republic. Like Kossmann 2000a: $133^{-66}$, I would, however, understand the rather rare notions of e.g. 'popular sovereignty' (Van Gelderen 1992: 209-12, 265-6) in a more traditional way, similar to their use in Althusius, whom the liberal German-American interpretation of C. J. Friedrich may also have made too much a modern constitutional federalist. Reacting to Jean Bodin's theory of sovereignty, German authors writing especially on the imperial ius publicum distinguished the maiestas realis of the empire from the maiestas personalis of the emperor. Such models of double sovereignty can legitimate a 'nation' as a whole bearing maiestas realis, if it opposes, as in the case of the Netherlands and Philip II, a king or tyrant with his maiestas personalis. I would maintain, against both Friedrich and Van Gelderen, that such a legitimation stems from the medieval idea of contractualism (dominium politicum et regale) and refers to the right of resistance in extremis, not to everyday republican rule within the body politic. 
delights of the courts. ${ }^{19}$ Three years later, a Discours that sought to expound the best way to govern the United Provinces contested this affirmation and recommended the Swiss constitution. The Discours considered it an imperium mixtum, but, unlike Grotius, as one consisting of both aristocracy and democracy: 'the government of the best nobles and the wisest citizens' which came to power through election. ${ }^{20}$

At the same time, Josias Simler gave a similar interpretation of the Confederation. He belonged to one of the best families of Zurich and was related to Ulrich Zwingli. Furthermore, he would remain the international authority on the Swiss constitution far into the eighteenth century, because his book De republica Helvetiorum, printed in 1576, was translated into German, French and Dutch and often reprinted. If one considers the marginal role of nobility in Switzerland and especially if one considers the later Swiss national ideology referring to a pact between burghers and peasants, an interpretation stressing the aristocratic aspect of the Swiss constitution may seem strange. Simler, however, not only contested the allegations of rebellion when he adopted the Aristotelian concept of the mixed constitution and insisted that the 'good' nobility had participated in the defence of the Swiss liberties against the Habsburg reeves, but also made clear that in doing so the Confederates had remained most loyal to the empire. The reeves had tried to alienate the empire's territories by subduing them; the Swiss had safeguarded them. Liberty, in the case of the Confederation, did not mean liberation from the empire, but liberty through and within the empire. ${ }^{21}$ Liberty was a privilege in the sense defined above, granted by the imperial, universal source of all legitimate secular power. This did not necessarily relate to a specific emperor who had accorded the privilege; after all, not much could be expected from the Habsburgs who had provided all emperors from 1438 onwards. The Swiss rather referred to the empire as an institutional framework that had established the legitimate basis for the cantons' lordship in their respective territories. Furthermore, only this ideal concept of empire could explain the archaic Swiss mixture of powers and privileges that generally belonged to the cantons, but to a small extent also to the Confederation itself.

The Swiss remained ideologically within the weak late medieval empire that had lacked almost all state institutions until 1495, when the Diet

19. Van Schelven 1947: 750-1; for Emanuel-Erneste see Mout 1988: 175, and Van Gelderen 1992:

171-2.

20. Discours 1583: fol. B2; Van Schelven 1947: 747-51, 754; Mout 1988: 178-9; Van Gelderen 1992:

187-91; Mörke 1999: 51-2.

21. Simler 1577: 4 . 
(Reichstag) of Worms agreed on reform and on a more integrative structure of the empire. ${ }^{22}$ The Confederates did not follow: neither did they become part of the imperial circle estates (Reichskreise) established to carry out the perpetual public peace agreed to in Worms, nor did they accept the imperial chamber court in Speyer and its practice of Roman Law. The Swiss cities had never been diligent visitors to the imperial diet and now stopped going there completely; nor did they receive any orders from the emperor. However, the Swiss cantons bore the empire's two-headed eagle on their coats of arms until well after the Peace of Westphalia of 1648 , when they received their 'exemption', their complete liberation from imperial jurisdiction. Formally, this was just another privilege granted within imperial law. However, with the spread of international law and the 'Westphalian system', the exemption was soon interpreted as independence and sovereignty, both in diplomatic practice and in legal theory.

The model for a republic in this system of monarchical sovereigns was originally Venice, but in the second half of the seventeenth century it became chiefly the successful United Provinces. The Dutch revolt had started as a defence of privileges against the Spanish. But the publication of Bodin's Six livres de la république in 1576 changed the way of thinking about political rule and its legitimacy. A Brief discourse justified the Dutch resistance as early as 1579 with sovereign rights, reserved to the States-General. ${ }^{23}$ They were ready to offer François d'Anjou - the French king's brother - the title of a 'defender of liberty', but refrained from adding the adjective 'sovereign' to the title, although he had claimed it on the advice of his personal counsellor Bodin. The Dutch feared that the French would understand it exactly in Bodin's sense as transfer of the 'puissance absolue'. ${ }^{24}$ In his Corte verthoninghe of 1587, François Vranck solved the problem by declaring that the States-General replaced the absent prince in representing the country's sovereignty. The regents and their councils thus became absolute rulers in their cities, without an interfering power above them, be it the former king or the stadtholder. ${ }^{25}$ Accordingly, the United Provinces insisted on attributes of sovereignty in diplomatic contacts, such as the title 'ambassador' for their diplomats, granted by France, England and Venice after the truce of $1609 .{ }^{26}$

22. See also Lee, Chapter 14 in this book, for the Diet of Worms and the Reichsreform. 23. Van Gelderen 1993: 136-9; see also xxiii-xxiv and Van Gelderen 1992: 144-5.

24. Secretan 1990: 77-82, 91-8, 91 for the quotation; Griffiths 1970: 73-7; Kossmann 2000a: $144^{-6 .}$

25. Van Gelderen 1992: 199-207; Secretan 1990: 106-11.

26. Besold 1624: 127-45, 138 (Praecedentia) for the quotation. 
The States-General referred to this exact precedent and to their 1639 Ceremoniale when their ambassadors defended their role as representing a strong and sovereign state, 'een Souveraine ende maghtige Staet representerende', during the negotiations in Westphalia. ${ }^{27}$ At that point it was the French who started contesting the Dutch position in protocol. As for Spain, in the peace treaty of 30 January 1648 it accepted the United Provinces as 'liberos \& supremos Ordines, provincias ac terras', which the French translated as 'libres et souverains Etats, provinces et pays', free and sovereign estates, provinces and lands. ${ }^{28}$

The relation with the empire was not mentioned in the peace treaty and hence remained ambiguous, so that some Germans contested the complete independence of the United Provinces. ${ }^{29}$ But unlike the Swiss exemption, the treaty with Spain was made on the basis of international law. Monarchs, and eventually even their life-long foe Louis XIV, accepted the Netherlands as sovereign and consequently as their peer. $3^{30}$ The Dutch referred to their sovereignty when they spoke of aurea libertas as Hendrick de Keyzer named one allegory on William the Silent's tomb in Delft (1621). $3^{31}$ Accordingly, Dirk Graswinckel defined libertas as the synonym for what monarchies called majestas: the sovereign power to legislate without any restrictions from a terrestrial power. ${ }^{32}$ Arguably, Paulus Busius was the first Dutch writer not only to discuss Bodin, but to clarify that the sovereignty of a republic was as absolute as that of a king: 'Imperium Reipublicae summum et absolutum, seu Potestas reipublicae suprema et legibus soluta. ${ }^{33}$

This was the lesson the Swiss still had to learn after French diplomats hinted at the Dutch example in the run-up to the Westphalian negotiations: like the States-General, the Confederates should not refer to privileges, weak

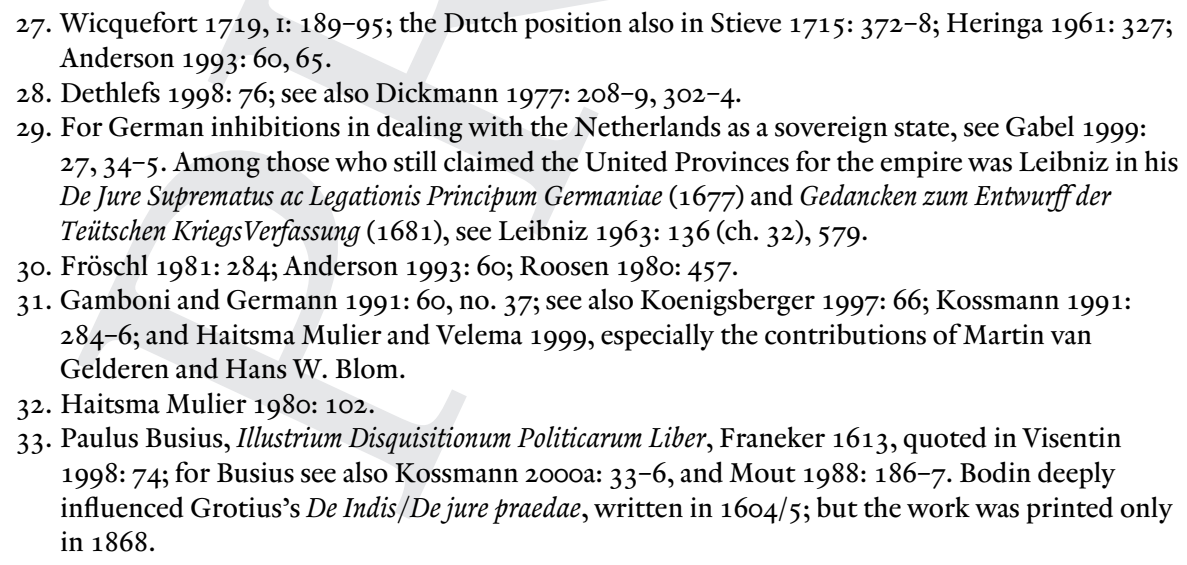


titles within imperial law, but rather claim the liberty that they had won and defended themselves by force of arms - and not received from anyone else. ${ }^{34}$ Although the Swiss envoy in Münster accordingly claimed that he wanted to keep the time-honoured sovereignty of his country intact, he eventually was not concerned when he only received the mentioned title of 'exemption'. ${ }^{35}$ It coped much better with the Swiss situation than the concept of 'sovereignty', which implied difficult questions: who, after all, was sovereign, the Confederation itself or the cantons? Hence, it is not surprising that the petty Catholic cantons, those which feared the superiority of the big Protestant cantons Zurich and Berne, should have ideologically gone on to justify their statehood within the framework of the empire. Nidwalden and Obwalden adorned their town halls with two-headed eagles as late as 1714 and 1733 respectively, and Obwalden, Appenzell Innerrhoden and Schwyz minted coins with two-headed eagles into the 1740 s.

But even in the Reformed cities, a deliberate shift from imperial symbols to the modern ones representing republican sovereignty only rarely occurred, as in 1698 when Zurich built a new town hall according to a clear political and artistic concept. ${ }^{6}$ Well into the eighteenth century, liberty or rather libertates in the plural meant, for most Swiss, essentially the privileges to rule and to judge, which the emperor had accorded them in the late Middle Ages. These were collective privileges owned by the Swiss cities or rural communities. To belong to such a collective, one had to be a citizen with full rights, which meant being personally free, not a serf, politically free, not a subject, owning property and de facto also belonging to one of the governing (regimentsfähige) families. The latter could be very limited, fewer than a hundred families in a big canton such as Berne, although theoretically all male adults in the ruling cities and rural cantons could claim full citizenship. To borrow Isaiah Berlin's terms: the Swiss cantons enjoyed negative liberty both from and within the empire, which remained the all-encompassing universal structure for some of them until about 1750 ; and the citizens enjoyed positive liberty within their respective cantons where they participated practically or theoretically in government or at least profited from economic privileges. 37

Positive liberty, but also merely living in the Swiss cantons, depended furthermore on some preconditions that were so obvious that they did not even have to be declared. Citizens and subjects equally had to adapt to

34. Eidgenössische Abschiede, v, 2: 1383 .

35. Eidgenössische Abschiede, v, 2: 2268-9; also 2262; Wettstein 1651: 17; Gauss and Stoecklin 1953: 193-4.

36. For examples see Maissen 2006: 383-400, 431-567. 37. Berlin 1958; Skinner $2002 \mathrm{~d}$. 
uniformity, particularly in the religious field. There was no negative liberty in the modern individualist sense of, for example, freedom of conscience, freedom of expression, freedom of the press and freedom of public worship. The two confessions cohabitated only on the highest political level, the Confederation and its diet, while in general, Catholics and Protestants were clearly separated in mono-confessional cantons. Appenzell was even formally divided according to confessional lines, and the same thing happened de facto to Glarus, the only bi-confessional canton. There was a denominational mixture within some joint dependencies (Gemeine Herrschaft) because they were ruled by cantons of a different creed. In those areas, especially in the Thurgau, Protestants and Catholics could even live in the same village and sometimes shared the local church (simultaneum). Thus they were forced to develop secular strategies of cohabitation and informal rules, a political culture of avoiding clashes on religious issues.

Behind such behaviour, there was no respect for the other confession, let alone toleration, but merely the pragmatic insight that civil wars were a worse evil than coping with the unloved neighbour. Such pragmatism was a sacrifice, and many people were not ready for it, as for example Giovanni Baptista Stuppa, a Calvinist from the Grisons and a lieutenant-colonel in a regiment commanded by his brother Peter Stuppa that helped Louis XIV invade the Netherlands. In his pamphlet La religion des Hollandais (1673), which was even printed in English (1680), Giovanni Baptista Stuppa tried to convince his fellow Swiss Reformed that any solidarity with the Dutch Calvinists was misplaced. Unlike the Swiss, they were not sincere Calvinists, but had established that same faith as a 'publick Religion ... out of pure interest of State'. The proof of religious indifference was that 'the United Provinces did not only permit the exercise of all sorts of Religions, but did also reject as Tyrannical, all the Laws, whereby there was any prescription made for Uniformity of Sentiments'. Hence the Dutch provinces were full of sectarians, and they extended toleration even to a Jew called Spinoza, who was about 'to destroy all Religions, and particularly the Jewish and the Christian, and to introduce Atheisme, Libertinisme, and the free Toleration of all Religions'.$^{3}$

When arguing against the freedom of religion, Stuppa could appeal to convictions that most people shared in early modern Europe. A ruler who tolerated different denominations was considered religiously indifferent and thus provoked the wrath of God against him and his nation. In a more secular perspective, to be fellow-citizens meant sharing convictions and values; 
most Europeans agreed that multi-religious societies lacked a common moral basis and therefore would suffer discord, vice and crime. Moreover, religious minorities could become a fifth column and side with the enemy who shared their faith, or they could try to become a political body of their own and split the nation. Religious unification was a precondition for political unity, especially in republics. As they lacked a king who could make quick decisions and impose equal rules on everyone, they were considered as suffering from political inefficiency and discord. Because of these shortcomings in institutional structure, the moral appeal to unity and concord was omnipresent in the republics and manifest in historiography, rhetoric and illustrations. 39

In Stuppa's view, certainly not disinterested, but also in the view of most of his contemporaries, individual freedom was a deadly menace to collective liberty. It could provoke instability and anarchy, and end in civil war, and that was what republics had to fear most. The identification of liberty with anarchy was one of the strongest rhetorical weapons of absolutist kings who liked to point at the English interregnum or the French fronde to show the effects of diversity when tolerated. Seen from an early modern perspective, Stuppa condemning his fellow Calvinists in the Netherlands is less surprising than Dutch toleration itself: why did the Dutch not only concede religious freedom, but even justify it theoretically?

As a matter of fact, not only William of Orange but also some regents had proclaimed 'freedom of religion' from the beginning of the revolt, first in 1572. According to article XIII of the Union of Utrecht, all individuals enjoyed freedom of religion. During the Reformation in general, that claim, however, was not a matter of principle, but provisory and instrumental. The Reformed asked for freedom of religion until their own faith, the only true one, would become the creed of the majority. Consequently, the Dutch Calvinists and the regents as well, who feared discord within their cities, proved from the 1570 on onwards their intolerance not only of Catholics, but also of Lutherans, Anabaptists and Jews. The Reformed infighting between Arminians and Counter-Remonstrants took place to impose the right conviction, not to foster toleration. It was only after the Arminians officially lost that battle at the Synod of Dordrecht (1618) that some of them, like Johannes Uyttenbogaert and Simon Episcopius, developed in the late 1620 s their irenic and latitudinarian positions of connivance into a more general idea of toleration as liberation from any kind of coercion in matters of religious conscience. ${ }^{40}$

39. Van Gelderen 2008; Maissen 2008. 40. Israel 1995: 372-7; 1997: 3-11, 18-21. 
What was particular to the Netherlands, however, was that the Arminians (and whoever else wanted) could refer to an admired intellectual tradition going back to Erasmus of Rotterdam, who had insisted more on moral integrity (philosophia Christi) than on dogmatic orthodoxy, distinguishing between fundamentalia and adiaphora, essential elements and rites that were neither compulsory nor forbidden. There were always, in the Netherlands, convinced advocates of that Erasmian kind of toleration, which remained limited to the dialogue between Christian denominations. With this reservation, these Dutch authors went much further than Zwingli and his fellows who were, however, also deeply shaped by other aspects of Erasmus's teaching. In his famous dispute with Justus Lipsius, Dirck Volckertsz Coornhert insisted not only on the moral value of toleration, but also on its political benefit. According to him, it was not religious difference but persecution of supposed heretics that caused civic discord..$^{41}$ With a similar irenic goal, Hugo Grotius promoted an Erasmian and latitudinarian church (similar to the Anglican one) under public control with a minimal creed in order to avoid discord on religious grounds, thus preparing for Hobbes's reduction of public faith to the sentence 'Jesus is the Christ.' Historiography should take the place of theology as the ideological foundation of society. In the humanist tradition, Grotius insisted not on religious uniformity, but on the individual virtue of the citizens as a precondition for good political order. He was elitist and indifferent in constitutional matters. An aristocrat could be virtuous, but so could a king; it was essentially a matter of education. ${ }^{42}$

In the Netherlands, systematic republican thought - claiming the superiority of the free state as opposed to monarchies in general and including not only a modern notion of individual liberty, but also a new reasoning about toleration - started only in the footprints of Descartes and Hobbes in the mid seventeenth century. That implied a methodological shift, because human beings were no longer considered, as in the humanist tradition, as differently gifted subjects of good education. They were seen as objects of their own passions and emotions and hence as essentially equal in these shortcomings. Pieter and Johan de la Court adopted not only this negative anthropology of Hobbes, but also his understanding of a dreadful state of nature and of the sovereign state to escape it. Their solution, however, was not a monarchical Leviathan: if mankind was wicked, a king would be so too, and even more than powerless people. The imperfect nature of man asked for a republic

41. Van Gelderen 2008: 160-2; Israel 1997: 6-7.

42. Van Gelderen 2008: 162-4; Kossmann 2000a: 31-6. 
whose citizens would themselves enact the rational laws to which they then would submit. ${ }^{43}$ For the brothers De la Court, liberty consisted no longer in the defence of collective privileges, but in the freedom of an individual property owner. A major freedom was that of religious conscience and religious expression that individuals had had in the state of nature and could keep even after they agreed on the social contract. This was the case especially if they lived in a commercial republic like the United Provinces, where people from all over the world and therefore with differing beliefs came in contact. Thus, dissenting private faith should generally be tolerated, while the brothers De la Court believed that the state (and not a church) should define the rules of public worship in order to control all churches and avoid clashes of zealous priests. 44

Following the brothers De la Court and his own teacher Franciscus van den Enden, Spinoza insisted even more on the necessity that the state controlled the ius circa sacra and the clergy, and maintained public worship of a (civic) religion with a limited number of core tenets oriented towards public peace. ${ }^{45}$ In spite of many similarities, Spinoza's plea was more existential than that of De la Court, who supported toleration with a pragmatic negligence for matters of truth, while Spinoza fought for freedom of thought in a general sense, as a human and social need and as a means to overcome mystery and superstition. His position was unlike the 'Arminian' tradition going from Episcopius to its late exponent John Locke, which conceded toleration as a privilege that the state accorded to some organised congregations (but not to Catholics or 'atheists') in order to enable their coexistence and the believers'spiritual redemption. For Spinoza, toleration was not a concession to churches, that is to autonomous collectives. It was the result of individual freedom in its both morally and politically most important form, the libertas philosophandi..$^{6}$ Locke still wrote about liberties, privileges granted by a state ruling whether a particular position served the common weal or not, whereas Spinoza postulated liberty, a natural and unconditional right that the state must not touch, but must guarantee within a legal system adopted by a collective sovereign.

43. De la Court 1661: 256, 263-7; see also De la Court 1662: 105-10 (5, 4), 145-50 (5, 9), and 1669: 66, 401. For further information on the brothers see Blom and Wildenberg 1986.

44. De la Court 1662: $23(4,3)$.

45. Spinoza 1994a: 285-98 (ch. 19); for Van den Enden see Israel 2001: 175-7.

46. For a comparison of Spinoza and Locke see Israel 2000; 2001: 265-70; 1997: 25-30, who puts the De la Court brothers and Spinoza in two different categories ('liberal regents' versus 'radical republicans') which may be more justified when speaking about their consequences than about their position among contemporaries. 
Spinoza's individualism was essentially Hobbesian. He also perceived the social contract as the product of affects insofar as individuals - with all their defects, but using their major asset: reason - wanted to escape fear and despair in a purely egotistical attempt to save themselves (conatus sese conservandi). What emerged out of such a negative anthropology was not aristocracy, as was the tendency at least with Pieter de la Court. Spinoza pointed to democracy as 'the most natural form of state, approaching most closely to that freedom which nature grants to every man'.47 Furthermore, democracy was the only truly absolutist government, since the ruler and the ruled were the same: a continuous assembly of citizens decided on the spot what was right and what was wrong, without obligations to other parties or to custom. 'For if there be any absolute dominion, it is, in fact, that which is held by an entire multitude. ${ }^{38}$ This absolutist democracy corresponded best to the original freedom and equality in the state of nature and at the same time it guaranteed individual freedom in the state of society because every citizen participated in political decisions. According to Spinoza's last chapter in the Tractatus theologico-politicus, everyone was allowed to think, to believe and to say what he wanted in a free democratic state whose true purpose was, for its part, freedom (of the individual). 49

The brothers De la Court and Spinoza, both inspired by Hobbes, thus developed a coherent liberal and republican tradition in the Netherlands. Theirs was a radical solution even for the United Provinces, although the issue of toleration was rooted in the earlier traditions of Dutch thinking mentioned above. The brothers De la Court and Spinoza wrote their books during the so-called waare vrijheid, the two decades of 'true liberty' when the urban patricians with Jan de Witt at their head ruled without a princely stadtholder. When Louis XIV invaded the Netherlands in 1672 and De Witt was murdered by the populace in The Hague, William of Orange was immediately appointed stadtholder. His supporters embraced people like Petrus Valkenier, who was later to reside in Switzerland as mentioned above and who was not less a convinced republican than a convinced Calvinist. His kind showed little interest in issues such as toleration, but defended the right of resistance according to the Monarchomach tradition. Most of all, for obvious reasons these Orangists adhered to the older, Grotian paradigm of the mixed constitution, with the States-General as the aristocratic part and

47. Spinoza 2007: 243; see also Israel 2001: 270-2.

48. Spinoza 1951: $347(8,3)$; see also the chapters on sovereignty in Spinoza 2007: 208-37;

furthermore Haitsma Mulier 1980: 170-208.

49. Spinoza 2007: $252(20,6)$. 
the stadtholder as the monarchical head of the political body. According to them, the individual virtue of the few, and not political institutions matching universal imperfection, should keep the political machine running.

One of these republican thinkers was Gerard de Vries, a professor at the university of Utrecht, a champion of empiricism, a teacher of natural law from Grotius to Pufendorf and a declared foe of Machiavelli, Descartes and Hobbes. ${ }^{\circ}$ De Vries defended the classical and humanist conviction that honestum and utile must and could be combined in politics. De Vries matters here because a young student from Zurich, Johann Caspar Escher, wrote his thesis under his supervision. Escher was to become mayor of Zurich in 1740 , but in 1697 he was just one of the many Swiss Protestants who studied in the Netherlands. ${ }^{51}$ In his thesis on the liberty of the people, Exercitatio politica de libertate populi, Escher started by condemning Hobbes and princely absolutism and by defining liberty through a quotation from Cicero, one of his favourite authors: Libertas est potestas vivendi ut velis..$^{52}$ Such a freedom to live as one wants should not be understood in a libertine or in a liberal way. For Cicero, to be free implied the control of one's passions; Escher added the obligation to follow the duties imposed by God. The assumption that equality had ruled in the state of nature convinced Escher that the original government was democratic, because it allowed individual citizens to enjoy an equal degree of liberty. Out of this original democracy, monarchy or aristocracy could develop later because they were more efficient in controlling whatever evil the original sin bred among humans. ${ }^{53}$

If Escher conceded non-democratic constitutions as legitimate though imperfect options, he regretted that they would not preserve man's original liberties in an integral way. Furthermore, he repeatedly insisted that rulers had to stick both to the fundamental law and to the duties which they had to fulfil themselves as pious citizens without confining the libertas populi tacita, the unuttered liberty of the people. Assuming a people ceded unconditional power to a ruler, that cession would be void, because the citizens would thereby act against God's order to preserve themselves. The libertas imperantis, the ruler's liberty to do what he wanted, must be limited, and the more it was, the larger the libertas populi. It was protected best through a contract which ensured the explicit (expressa) liberty of the people, its fundamental

50. On De Vries see Kossmann 2000a: 93-7; Veen 1976: 233-4: Israel 2001: 479-80.

51. For Escher's life see Maissen 2006: 402-5, and the older biographies of Wyss 1790 and Keller-Escher 1885: 102-30.

52. The Exercitatio has recently been edited by Werner Widmer, see Escher 2008: 564 for the quotation from Cicero, Paradoxa Stoicorum, 34 .

53. Escher 2008: 580-6. 
laws and privileges and in particular religion, life, wealth and the election of lower magistrates. ${ }^{54}$ It is noteworthy that Escher distinguished between a bad ruler and a tyrant: the former could be bloodthirsty and even despise God and religion, but still respect 'public liberty'; the latter was ready to violate the people's liberty, be it for the public weal (salus Reipublicae). Of all rulers, Escher presented Augustus as a tyrant and referred to John Milton in maintaining that a sovereign forfeited his title by the very fact of becoming an absolute ruler and thus a tyrant. And if as a tyrant he no longer respected the jura ac libertas civium which he had granted in the social contract, without a doubt the people or rather the lower magistrates had the right to resist their prince and even kill him. 55

Escher thus combined elements of natural law probably taken from Pufendorf and the Dutchman (of Swiss origin) Ulric Huber ${ }^{56}$ with the Calvinist right of resistance found in Beza's De iure magistratuum, while his discussion of iura ac libertates referred to the medieval concept of (imperial) privileges. Several elements were not alien to Spinoza: democracy as the constitution closest to original equality and liberty in the state of nature; refusal of arbitrary rule; insistence on the right of resistance against it. But Escher did not have to read Spinoza to defend such positions that may have been deemed outrageous everywhere except among many Dutch authors. The republican De Vries, who repudiated Spinoza's 'irreligious' ideas, obviously did not object to his student's assertions.

However, Escher met resistance when he defended his eclectic thesis in Utrecht in a public disputation. In an autobiographical sketch, he later narrated the discussion that arose because he had maintained in his sixteenth thesis that the political authorities must uphold the unanimous religious creed of the people, once it had been defined by consensus populi and became a fundamental law. According to Escher, a government must punish individuals who wanted to spread new religious doctrines; the reason for doing so was not theological, because of the religious deviation, but political, because the lack of uniformity could provoke unrest within the state. According to Escher, even those citizens who did not manifest their dissenting faith

54. Escher 2008: 588-92, 598.

55. Escher 2008: 618-22; Escher ends with a quotation from Cicero, De officiis, 3,6 , justifying tyrannicide.

56. Ulric Huber printed his Dejura civitatis for the first time in 1672, but Escher could have used the revised edition of 1694. The Aristotelian Huber opposed Hobbes and interpreted the fundamental laws of the republic as the rights which the citizens preserved from the state of nature; if the ruler transgressed them, Huber agreed that the citizens had the right of resistance. Huber 1708: $306(1,9,6,30)$. 
openly in public could be expelled from the country. This assertion met fierce opposition in the audience. Many listeners were French Huguenots whom Louis XIV had forced into exile in 1685 . They claimed that no ruler was allowed to limit natural freedom in religious matters. According to them, Escher's sixteenth thesis contradicted the spirit of his whole dissertation on liberty. Escher first tried to defend his argument, but eventually capitulated. He conceded that he had developed his case from the perspective of a Zurich citizen, but that now he understood that a good Christian had to opt for politics of toleration in matters of conscience. 57

Escher's public conversion illustrates three different approaches to toleration and thus to individual liberty in the federal republics around 1700. As a citizen of Zurich, he first insists on the republican claim for religious unity to protect an otherwise unstable state: his libertas populi does not focus on individual rights, but wants to preserve the community as a whole from absolute monarchical rule. As for the Huguenot exiles, they require the toleration of their proper creed less as a matter of principle than for strategic reasons, at least if they belong to the faction of Pierre Jurieu: they want to reacquire the collective freedom to worship their own, infallible religion in their home country. The position of the De la Court brothers and of Spinoza is different. The diversity of religions stems from imperfect human nature and from the diversity of individual thinking. Hence the state accords freedom of religion as a natural right to its citizens as long as they do not provoke unrest; precisely to avoid turmoil, rulers have the right to control (public) churches and their creeds.

Another anecdote similarly illustrates the differences between the Swiss and the Dutch interpretation of liberty in the years around 1700. There was one recurrent matter of dispute in their usually cordial diplomatic relations. The tolerant Dutch reproached their allies in Zurich and Berne because they disagreed on how harshly the Swiss treated the Anabaptists. They were pursued and forced to emigrate without the right to take their property with them. The Dutch turned the issue into a universal argument for the freedom of conscience which brought to light quite different interpretations of republican virtues. As the pacifist Anabaptists refused military service, the United Provinces allowed them to exempt themselves from that duty and to pay a particular tax instead. For the Swiss, however,

57. Escher's Lebensgeschichte, a manuscript at the Zentralbibliothek in Zurich (FA Wyss III 116), is edited partially by Keller-Escher 1885 , I: 106-7, containing the story of his disputation; see also the controversial thesis 16 in Escher 2008: 598-602. 
citizenship rested on the ability and willingness to do military service in the militia. $5^{8}$

It may seem somehow ironic that the political ideal was commercial and peace-oriented in the Netherlands (and especially in Holland), although the country was constantly involved in wars, while Berne and Zurich fostered civic and military values although they were able to develop peacefully and export war through their mercenaries. This opposition can be explained by historical and structural differences which we will sum up in a conclusion in order to understand why the transition from liberties to liberty took so much longer in the Swiss case than in the Dutch.

1 Protecting (Calvinist) believers against a powerful, repressive state was one of the causes of Dutch independence, while the Confederates understood themselves to be a people elected by divine will when they became for few decades a European power, a position they definitively lost when religious uniformity broke apart in the Reformation. While the freedom to choose one's religion was at the origin of the Dutch miracle, it caused the Swiss decline.

2 However, not even in the Netherlands was there practical or theoretical continuity in dealing with religious dissent, and until at least the 1630 s a considerable gap remained between the (tacit) freedom of conscience and the freedom of open practice. More than the ideas of regents and philosophers, social and economic reality dictated a politics of toleration. Economic success provoked steady immigration from all over the world while the poor Swiss cantons turned away even wealthy refugees of their own creed, such as the Huguenots. The Swiss guilds feared competition within their corporative economy based on the ideal of cantonal autarchy through careful management of limited resources. To bar access to guilds, the ranks of citizenship closed completely in the seventeenth century for the subjects living in the same canton and even more for foreigners. Religious uniformity hence was also a means to enforce privileged exclusivity. The Dutch regents were more pragmatic because they dealt in international commerce and were used to differences. As urban merchants with a humanist education, they thought also more positively about individuality than the Swiss, where agriculture dominated and often imposed collective solutions and joint work.

3 In Switzerland, religious uniformity corresponded not only to social and economic life, but also to the almost absolutist grip that the cantons 
had on their relatively small and barely urbanised territories; there was little space for divergence. The situation was different in the commercial towns of Holland and especially in the metropolis of Amsterdam. While Swiss cantons were ruled by the homogenous elite of just one city, this was not the case in the Dutch provinces, especially in the commercial ones on the coast, where the different interests of cities of various sizes had to be co-ordinated. While the United Provinces formed a relatively strong and centralised state, compared to the Confederation, the Swiss cantons were strong petty states compared to the (urban) Dutch provinces. That is why they could impose religious uniformity on their territory but not in the joint dependencies administered moderately by cantons of both faiths; similarly, in some alpine areas (Glarus, Appenzell and the allied Grisons), communal autonomy was so highly developed that the canton itself became bi-confessional. The stronger the state, the better it could insist on homogeneity.

4 The Reformed cantons had a state church, and the Catholic cantons controlled their church tightly, even though they formally depended on Rome. Hence religious unity was easy to impose and corresponded with the shared needs of churchmen and politicians. The Dutch Calvinist was not a state church but a public church. Officials had to belong to it, but not the run-of-the-mill believers. Although the urban regents fought hard battles against Calvinist orthodoxy to bring the public church under the rule of the state, they never managed to have a partnership as close as that which existed within the Swiss cantons. The Dutch orthodox Calvinists themselves had serious inhibitions about an all-encompassing church. This would have meant including many half-hearted Dutchmen in a church that should be reserved to the devout.

5 As far as concepts of liberty were at stake, Swiss statehood depended on liberties of the empire. At the beginning of their revolt, the Dutch defended their ancient privileges too. But very soon they had to switch to an interpretation within the framework of international law and sovereignty conquered by the force of arms, not only to justify a revolt against a legitimate ruler and the resulting free state without a monarchical head, but also to define and limit the powers of the stadtholder. Unlike the exposed Dutch, the Swiss could go on interpreting their Confederation within medieval imperial law and its system of privileges or liberties granted to collectives (universitates in the medieval sense).

6 Such collectives always had to be distinguished from others and were defined through the features the members shared; in early modern Europe, 
the most important one, besides lordship, was religious denomination. Therefore, the Swiss could hardly conceive of their liberties without a common belief. In contrast, the concept of sovereignty opposed the single or collective - ruler to his subjects not as groups, but as individuals. Liberty was the appropriate word to describe the rights he (as an absolute ruler) conceded to them or they (in a free state) could claim against him. Religion was the early modern touchstone for liberty, because it could be conceived as the result of individual conscience or collective belonging. The different pace of toleration debates in the Netherlands and Switzerland is highly indicative of the slow transition from medieval liberties to modern liberty, a process only completed at the time of the French Revolution. 59

59. See Velema 2007: 139-57, for the changing concept of liberty during the decisive years of the patriotic revolt in the 1780s; for Switzerland during the same time see Weinmann 2002. 